most standard references. . . . I like the theme of continuity and change. An additional change might be to drop the sentence about the post office not forwarding periodicals. However, I must confess a certain nostalgia over such blatant errors.

$$
\begin{aligned}
& \text { Sincerely, } \\
& \text { Joseph J. Lauer } \\
& \text { Editor, Sahel Bibliographic } \\
& \text { Bulletin }
\end{aligned}
$$

Editors note: Fools rushed in where Angels feared to tread. See back page.

\title{
ANOTHER COMPUTER VICTIM
}

\section{Dear Editors:}

I write this letter with much trepidation! I am aware that in our computerized society, the individual who requests the correction of a computerized error exposes himself/herself to humiliation and annoyance and in turn is exposed to the paralysis possible with modern technology. I brave my chances.

I received two copies of $A S A$ News, January/March, 1981. The error is in the computerized address label. . . . I pray, as I shudder, that my "affront" at the computer will not cancel my ASA membership, ASA News, African Studies Review and Issue!

\section{Peace,}

Kofi R. Glover, Ph.D.

Editors note: We print this note from Dr. Glover as a sort of apology to him and to others who have been inconvenienced by the born again ASA mailing list.

\section{LIBRARIANS CONFRONT ASA NEWS}

Dear Don:

. . . I I feel it is incumbent upon me to scold you for changing the title of ASA News. You have caused the generation of countless new Kardex cards, catalog cards, and on-line cataloging records. Think of the paper, ink, man-hours and electricity that you have used up. Aside from this quibble, the new format looks great, and I like the new features.

Best Wishes,

Gretchen Walsh

African Studies Library

Boston University

PROTEST NEW AMERICAN POLICY IN AFRICA

The editors of the $A S A$ News received a copy of the following letter:

7 April 1981

Dar es Salaam

President Ronald Reagan

Tanzania

White House

Washington, D.C.

Dear Mr. President:

As U.S. citizens living and working in Tanzania, we are deeply concerned about recent reversals and shifts in our government's foreign policy. 
Your administration, with military and food aid as its muscle, seems bent on aligning itself with such repressive regimes as South Africa, Chile and El Salvador and, at the same time, reversing positive initiatives towards the achievement of a more just world order.

Because we live and work in a poor African country, we are in a position to see the deteriorating relations between the U.S. and many Third World countries in the few months since you took office.

Viewed from our perspective here, the world cannot be simplistically divided into pro-American and pro-Soviet camps. The majority of African countries are non-aligned. Their concern is much more with poverty and underdevelopment than with East-West rivalry.

Tanzania, a leader in the non-aligned movement, had a good working relationship with the last Administration but this is being scuttled by your Administration's policies and pronouncements. Moderate African governments which have been traditional friends and allies of the U.S., such as those in Kenya and Nigeria, are now appalled by recent Administration statements. These include your declaration of friendship towards South Africa, the Administration's seeming indifference towards the UN-sponsored Namibian negotiations, the failure of the U.S. to condemn a South African attack on a suburb of the Mozambican capital and Administration attempts to repeal the Clark Amendment so as to clear the way for U.S. aid to South African-backed guerrilla in Angola.

Those who have been arguing for years that the U.S. is an ally of South Africa now seem to be having their case proven. U.S. prestige among Africans, with the exception of white South Africans, is falling rapidly.

With the increase in defense spending and the military build-up in such areas as the Indian Ocean, your Administration seems determined to have international affairs settled on the battlefield rather than around the conference table. Even positive steps towards settling the world's problems peacefully, such as those taken at the Law of the Seas Conference, and initiatives toward global negotiations on the world economy, are being negated.

Food, a basic right of all humans, has been turned into a political weapon to be used against Mozambique, Nicaragua and any other country that fails to align itself with the U.S. Such a policy will only drive those countries further from the U.S.

Until your Administration took office, relations between the U.S. and black African states had been improving, and there is much to be gained from this.

We call on our government to turn away from the course of confrontation and the pursuit of narrowly-defined interests which it has chosen.

SIGNED BY 110 US CITIZENS LIVING AND WORKING IN TANZANIA

Names available on request from: Michael J. Schultheis

Univ. of Dar es Salaam

P. O. Box 35096

Dar es Salaam, Tanzania

\section{A VOICE FROM THE PAST}

Dear friends,

Members Huff and LeVine should know that the $\$ 40,000$ membership originated in the former office of the Association as a well intended typographical error. It was our last big mistake and I am sorry it caused you people trouble. 